\title{
Occurrence and Distribution of Varroa Mite and Antivarroa Effect of Propolis in Walmara District of Oromia Special Zone Around Finfine, Ethiopia
}

\author{
Ebisa Mezgabu ${ }^{1}$, Eyob Hirpa ${ }^{1 *}$, Dasselegn Begna², Lama Yimer ${ }^{1}$, Abdisa Bayan ${ }^{3}$ and Misganu Chali \\ ${ }^{1}$ School of Veterinary Medicine, Wollega University College of Medical and Health Science, PO Box 395, Nekemte, Ethiopia \\ ${ }^{2}$ Holeta Research Institute, Bee Research Center, Holota, Ethiopia \\ ${ }^{3}$ Gudeya Bila Veterinary Clinic, Ethiopia \\ ${ }^{4}$ Haru District Jeto Veterinary Clinic, Ethiopia
}

\begin{abstract}
A cross-sectional study was carried out from November, 2014 to April, 2015 aimed to assess the occurrence, infestation rate and associated risk factors of Varroa mite on Honeybees; investigation of the effect of propolis on varroa mites in Walmara District. Purposive sampling was used in Peasant Association; twelve apiaries and sixty four hives were randomly selected for inspection. Interviews, direct observation and experimental set up were the main data collection techniques used to gather the information. The results revealed the whole (384) bee colonies examined for Varroa mites were Positive with varies infestation range $4 \%-53 \%$ in brood and $4 \%-36 \%$ in adult Honeybees. The highest Adult infestation rate $18.20 \pm 7.99 \%$ of Varroa mites was observed in Tullu Harbu, while the lowest infestation rate $(14.25 \pm 5.12 \%)$ was observed Wajitu Harbu. on other side The highest Brood infestation rate $(22.76 \pm 9.64) \%$ of Varroa mites was observed in Nano Suba, while the lowest infestation rate $13.73 \pm 5.88 \%$ was observed Wajitu Harbu. Infestation levels showed significant relationship with colony type $(p=0.006)$. Weak colony type is highly infested than strong colony, However, associated risk factors including age, sex, educational status, duration of experience of Beekeepers, and site and hive type were not showed statistical significance with Varroa mite infestation $(P>0.05)$. Effect of Propolis against Varroa Mite has been investigated and showed lethal effect. Propolis extracted with $70 \%$ ethanol was found to be highly toxic, at $20 \%(\mathrm{w} / \mathrm{v})$ of propolis resulting in $94.44 \%$ mortality with a brief contact time of $5 \mathrm{sec}$. The study showed that whole bee colonies examined were co-existed with the mites and lethal effect of propolis on Varroa mites. Therefore, improved management system and further research to use propolis extract as a treatment option was recommended.
\end{abstract}

Keywords: Honeybee; Infestation; Propolis; Varroamites; Walmara

\section{Introduction}

Most Honeybee researchers consider the ectoparasitic mite Varroa destructor ( $V$. destructor) to be the most damaging enemy of the Honeybee. It has been recently identified as one of the major factor responsible for colony losses worldwide [1]. No other pathogen has had such a large impact on beekeeping or Honeybee research through the history of apiculture. The mite weakens the Honeybees immunity and their susceptibility to other environmental stressors and vectors lethal Honeybee viruses [2].

Varroa mite was originated from South-East Asia and was originally confined to the Eastern Honeybee Apis cerana (A. cerana). After a shift to the new host the Western Honeybee, Apis mellifera (A. mellifera), during the first half of the last century, the parasite has become widespread across most continents. The mite is spread by foraging and swarming bees and Varroa females are transported on adult bees to brood cells for reproduction. Shortly after leaving the brood cell on a young bee, the mites preferentially infest nurse bees for transport back to the brood cells. This may be an adaptive strategy for the Varroa females to increase their reproductive success [3].

The mite feeds on the bee by injuring the cuticle of the pupae and sucking substantial amounts of haemolymph. The haemolymph is an insect's equivalent to blood, distributing nutrients throughout the bee, including immune components which form one of the primary lines of defense against invading microorganisms [4].

The threat of Honeybee infestation by $V$. destructor forces Beekeepers in many parts of the world to treat their colonies with acaricides, which are associated with drawbacks. The most serious drawbacks are the buildup of residues in bee products [5] and the development of resistant mite strains. The problems associated with the use of acaricides provide considerable incentive to develop new treatment strategies and screening for potential acaricides that minimize these problems. Natural products having components with various modes of action might provide effective solution to the problem of varroosis [6]. One of such natural products is propolis, a complex mixture of several compounds collected by honeybees from plants, mixed with wax and used in the construction and protection of the beehive [7].

Propolis is a natural remedy that has been used extensively since antiquity. The Egyptians, who knew very well the anti-putrefactive properties of propolis, used it for embalming [7]. It was recognized for its medicinal properties by Greek and Roman physicians, such as Aristotle, Dioscorides, Pliny and Galen. The drug was used as an

*Corresponding author: Eyob Hirpa, Assistant Professor, School of Veterinary Medicine, Wollega University, PO Box 395, Wollega, Ethiopia, Tel: +251933686525 E-mail: eyobresearch@gmail.com

Received July 19, 2016; Accepted August 01, 2016; Published August 05, 2016

Citation: Mezgabu E, Hirpa E, Begna D, Yimer L, Bayan A, et al. (2016) Occurrence and Distribution of Varroa Mite and Antivarroa Effect of Propolis in Walmara District of Oromia Special Zone Around Finfine, Ethiopia. J Vet Sci Technol 7: 370. doi: 10.4172/2157-7579.1000370

Copyright: @ 2016 Mezgabu E, et al. This is an open-access article distributed under the terms of the Creative Commons Attribution License, which permits unrestricted use, distribution, and reproduction in any medium, provided the original author and source are credited. 
antiseptic and healing in the treatment of wounds and as a mouth wash, and its use in the Middle Ages perpetuated among Arab doctors [8]. Also, it was widely used in the form of ointment and cream in the treatment of wounds in battle field, because of their healing effect. This healing property of propolis is known as "Balm of Gilead," is also mentioned in the Holy Bible [9].

From the pharmacological point of view, propolis has been used as solid; in an ointment based on Vaseline, lanolin, olive oil or butter, and in the form of alcoholic extract and hydro alcoholic solution. The proportion propolis/carrier may vary, in order to obtain bacteriostatic or bactericidal results. In Dentistry, there are studies investigating the pharmacological activity of propolis some situations, such as gingivitis, periodontitis, oral ulcers, pulp mummification in dogs' teeth and dental plaque and caries in rats [10]. Also, it has been used in dressings of pre and post-surgical treatment, oral candididosis, oral herpes viruses and oral hygiene. The global interest in propolis research increased considerably in relation to its various biological properties [11].

Literature on the acaricidal or insecticidal action of propolis is very limited. It has been assumed that components of nectar, pollen and propolis may adversely affect the development of $V$. destructor in the hive of some bee populations. Some authors proposed that some flavonoid components of propolis have insecticidal or at least insect static (inhibition of insect larval development) effects [12,13].

Even though our country is rich with different floras and climate which are conducive for Beekeeping, honey and other hive product production is limited due to many problems like pests infestation of honey bee colonies. Of these pests, Varroa mite causes huge impact. This impact can be solved by using a natural product, propolis.

Therefore, the study was designed with the following objectives:

- To assess the occurrence and infestation rate of Varroa mite in Walmara District and

- To investigate the effect of propolis on varroa mites.

\section{Materials and Methods}

\section{Study area}

The study was conducted in central high land of Ethiopia, in Oromia special zone around Finfine in Walmara District from November, 2014 to April, 2015. Walmara District is located at $25 \mathrm{kms}$ to the West of Addis Ababa $\left(8.5^{\circ}-9.5^{\circ} \mathrm{N}\right.$ and $\left.38.4^{\circ}-39.2^{\circ} \mathrm{E}\right)$ with altitude of $2000-3380$ meters above sea level. It has annual rain fall and temperature ranging from $334-1350 \mathrm{~mm}$ and $5^{\circ} \mathrm{C}-27^{\circ} \mathrm{C}$ respectively. Walmara District has number of livestock on the basis of species as 188221 cattle, 108652 sheep, 15420 goats, 365294 poultry, 8062 horses, 229 Mules and 1853 traditional, 870 transitional 843 modern bee hives with the estimated human population of 83,784 and the district has large forest, shrubs and herbs. It is bordered by Burayu town to the East, Ejere District to the west, Sululta District to the North and Sebeta Hawas District from the south and its weather condition is classified as 39\% Woinadegaand 61\% dega respectively (Walmara District Livestock and Agricultural Office 2014).

\section{Study populations}

Study populations included honeybee colonies found in the selected Peasant Associations of Walmara District and respondents (Beekeepers).

\section{Study design}

A cross sectional study was conducted in Beekeeping potential areas of Walmara District. Prior to the actual survey, information was gathered from secondary data from reports of the District's Agricultural Development Office and informal consultation with key informants.

\section{Sample size determination and sampling technique}

The total number of Bee colonies sample needed for the study were calculated by the rule of thumb, where there is no information for an area, it is possible to take $50 \%$ expected prevalence. The $Z$ value of 1.96 is used at $95 \% \mathrm{CI}$ and margin of error is $5 \%$ ( $\mathrm{n}=$ sample size, $\mathrm{P}=$ proportion, $\mathrm{D}=$ margin of error [14]. Accordingly, the sample size (n) of the study is calculated as follows,

$$
\mathrm{n}=\frac{1.96^{2}(\mathrm{p})(1-\mathrm{p})}{\mathrm{d}^{2}}
$$

Where $\mathrm{n}=$ sample size; $\mathrm{p}=$ Expected prevalence; $\mathrm{d}=$ Desired level of precision (5\%); $\mathrm{n}=384$

\section{Study methodology}

Questionnaire survey and sampling procedure: Potential beekeeping Peasant Associations were identified in Walmara District according to the information gathered from Holeta Bee Research Center and secondary data from reports of the District's Agricultural Development Office and informal consultation with key informants Based on the information obtained from secondary data and informal survey, a structured questionnaire was developed and pre-tested for its consistency and applicability to the objectives of the study.

Based on this information, six Honeybee colonies potential Peasant Associations administrations including: Gole Liban, Nano Suba, Wajitu Harbu, Dawaf Lafto, Gebarobi and Tullu Harbu were selected out of thirty four Kebeles administrations in the district. Per selected Peasant Associations Administration, twelve model beekeepers, a total of seventy two respondents were selected by using purposive sampling technique and interviewed. Simultaneously, samples of broods and adults of Honeybees from the hive of each of the seventy two selected model Beekeepers randomly. Therefore, seventy two apiaries were sampled from the selected Peasant Associations, sixty four from each of the six Peasant Associations with a total of 384. Of the 384 colonies $129,127,128$ were from traditional, transitional and modern hives respectively. One colony was counted as one sample. These colonies were sampled by using random sampling method by taking adult honey bee and brood samples from each colony the sample was taken to HBRC Laboratory for the diagnosis purpose. Sampling was carried out during the night to prevent bee sting and colony disturbance.

Adult and brood of honey bee sample collection: Samples of approximately 200-300 worker bees were taken from the brood chamber of the hive to determine the phoretic Varroa mite infestation rate on adult bees. The bees from each sample, which were 250 in number counted and then washed in soapy water to dislodge the mites. Using a strainer the mites were separated from the bees and were counted to calculate the proportion of mites per bee. Similarly, Samples of brood were collected by selecting an area of $5 \times 5 \mathrm{~cm}$ in the middle of a worker comb. The cells were scratched and all stages of Varroa females in each cell were counted [15].

Propolis collection, preparation and extraction: Propolis sample used in the experiment was obtained by scraping off from frames of honey comb sampled from Gole Liben Peasant Association. Then, the 
Citation: Mezgabu E, Hirpa E, Begna D, Yimer L, Bayan A, et al. (2016) Occurrence and Distribution of Varroa Mite and Antivarroa Effect of Propolis in Walmara District of Oromia Special Zone Around Finfine, Ethiopia. J Vet Sci Technol 7: 370. doi: 10.4172/2157-7579.1000370

Page 3 of 6

collected propolis was weighed and frozen sample was homogenized using a coffee mill. The homogenate powder was then extracted in $70 \%$ ethanol. For effective extraction, the propolis powder was suspended in the corresponding ethanol solution in a ratio of $1: 9(\mathrm{w} / \mathrm{v})[16]$. The suspension was extracted in a rotary evaporator at $60^{\circ} \mathrm{C}$ for 2 hours. The suspension was then cooled at room temperature for 1 hour and suction filtered. The filtrate was dried in an incubator at $40^{\circ} \mathrm{C}$ to weight constancy, which was achieved in two weeks' time. The $70 \%$ ethanol extract was used in 55\% ethanol in the bioassay to reduce the effect of strong ethanol solution on the experimental organisms. The concentrations used in the bioassay were $5 \%, 7.5 \%, 10 \%, 15 \%, 20 \%$ $(\mathrm{w} / \mathrm{v})$. However, the acaricide residue analysis of propolis was not performed. These activities were carried out in Holeta Bee Research Center Laboratory.

Varroa mite collection for experiment: Varroa Mites used for the experiment were collected from infested colonies of Holeta Bee Research Center apiary according to Garedew et al. [17]. The combs containing broods and infested with Varroa mites were taken and brought to. Then, cells were uncapped and broods were removed from the cells and mites were collected from it. In order to avoid starvation of the mites, they were kept in a Petri dish on bee larvae or pupae. Collection of mites was done from both the larval and pupal stage of healthy brood.

Bioassay: Treatment of the mites was done in Holeta Bee Research Center Laboratory, by applying $250 \mu \mathrm{L}$ of a given concentration of propolis on a $3 \mathrm{~cm} \times 3 \mathrm{~cm}$ tissue paper in a Petri dish and by immediately placing six mites per experiment on the wetted tissue paper. To observe the effect of contact time of propolis on the activity of $V$. destructor, the following treatment times were used: $5,10,20,30$, $40,60,75$ and 90 seconds. The treatment was stopped after the allocated time by removing the mites with the tissue paper from the Petri dish and immediately placing them on a pad of paper towel for 1 minute to blot the excess fluid from the surfaces. They were then transferred to a clean Petri dish and their activity was observed under a dissecting lens every five minutes for the first hour, every 10 minutes for the next one hour and every 30 minutes for the next two hours. All treatments were done at room temperature. Control experiments for each experimental group were done by treating the mites with distilled water at the corresponding times. An individual was considered inactivated if it showed no leg movement or movement of any body part when gently prodded with a probe. If it showed movement it was counted as alive, irrespective of whether it was partially paralyzed or normal. If the inactivation lasted more than four hours after the treatment time, the mites were considered dead. Each treatment was repeated three times and the mean values, and in some cases the Mean \pm Standard deviation values, were used in the presentation of results [17].

\section{Data management and analysis}

Collected data were stored in Microsoft Office Excel 2007 and analyzed by SPSS software version 20 for presentation of the results.

\section{Results}

\section{Adult and brood of honey bees diagnosis result}

This study showed that all the sampled Peasant Associations were tested positive to varroa mites. A two hundred fifty Bees per colony were examined through adult bee colonies and an infestation rate of $15.73 \pm 6.903$ (ranging from 4-36) varroa mites were recovered (Table 1). Although there was no much difference infestation rates between Peasant Associations, the result revealed Tullu Harbu, Geba Robi,

\begin{tabular}{|c|c|c|c|}
\hline Sample type & Sample No & Prevalence & Infestation Rate(Range) \\
\hline Brood & 384 & $100 \%$ & $18.07 \pm 7.03(4-53)$ \\
\hline Adult & 384 & $100 \%$ & $15.73 \pm 6.903(4-36)$ \\
\hline
\end{tabular}

Table 1: Prevalence and infestation rate in different sample type.

\begin{tabular}{|c|c|c|c|}
\hline Kebeles & Sample type & Colonies sampled & Average infestation rate \\
\hline \multirow{2}{*}{ TulluHarbu } & Brood & 64 & $19.41 \pm 6.59(5$ to 33$)$ \\
\cline { 2 - 4 } & Adult & 64 & $18.20 \pm 7.99(4$ to 36$)$ \\
\hline \multirow{2}{*}{ GebaRobi } & Brood & 64 & $20.69 \pm 9.57(5$ to 33$)$ \\
\cline { 2 - 4 } & Adult & 64 & $16.52 \pm 7.35(5$ to 35$)$ \\
\hline \multirow{2}{*}{ Nano Suba } & Brood & 64 & $22.76 \pm 9.64(8$ to 53$)$ \\
\cline { 2 - 4 } & Adult & 64 & $15.02 \pm 7.18(5$ to 33$)$ \\
\hline \multirow{2}{*}{ DawafLafto } & Brood & 64 & $17.94 \pm 6.79(6$ to 36$)$ \\
\cline { 2 - 4 } & Adult & 64 & $15.22 \pm 6.89(6$ to 36$)$ \\
\hline \multirow{2}{*}{ GoleLiben } & Brood & 64 & $13.91 \pm 5.74)(5$ to 30$)$ \\
\cline { 2 - 4 } & Adult & 64 & $15.15 \pm 6.00(6$ to 34$)$ \\
\hline \multirow{2}{*}{ Wajituarbu } & Brood & 64 & $13.73 \pm 5.88(4$ to 34$)$ \\
\cline { 2 - 4 } & Adult & 64 & $14.25 \pm 5.12(6$ to 27$)$ \\
\hline
\end{tabular}

Table 2: Infestation rate at different peasant association.

\section{Varroa Mite on Brood}

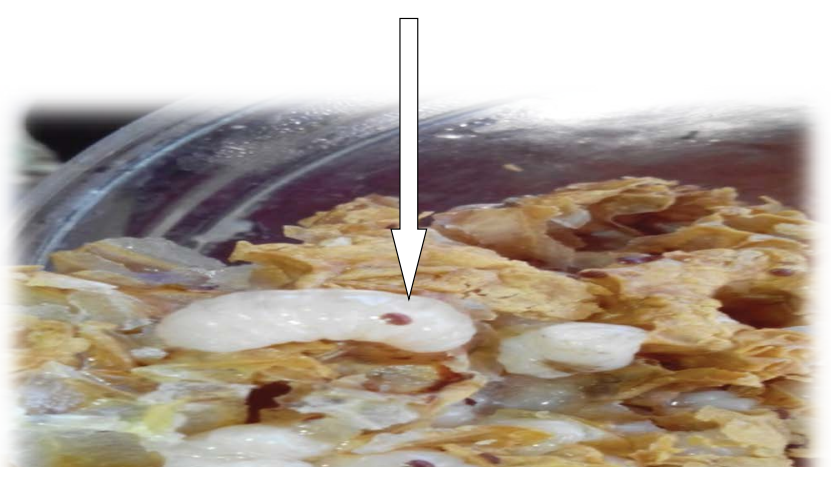

Figure 1: Brood infested with Varroa mite.

Dawaf Lafto, Gole Liben, Nano Suba, and Wajitu Harbu with $18.20 \pm$ $7.99,16.52 \pm 7.35,15.22 \pm 6.89,15.15 \pm 6.00,15.02 \pm 7.18$ and $14.25 \pm$ 5.12 from the highest to the lowest respectively (Table 2 ). Therefore, overall varroa mite prevalence in Walmara District was $100 \%$. In the similar way, all of the bee colonies diagnosed for adults were also diagnosed for brood, and found positive with Varroa mites (Figure 1). This also revealed that all the sampled Peasant Associations were infested with these mites and Brood bee shows high infestation rate than Adult bee even though it's not statically significant $(\mathrm{P}>0.05)$. The highest infestation rate was recorded in Nano Suba $(22.76 \pm 9.64)$ while lowest was recorded in Wajitu Harbu $(13.73 \pm 5.88)$ This indicated that Nano Suba and WajituHarbu Peasant Associations were found with highest and lowest varroa mite infestation rates respectively (Table 2). Regarding associated risk factors and Varro mite infestation, there is no statistically significant variation for type of Hive, type of sample and Peasant association $(\mathrm{P}>0.05)$ except Colony type showed Significant variation, Thus weak colony was highly infested than Strong colony $\left(\mathrm{X}^{2}=78, \mathrm{P}=0.006\right)$.

\section{Anti varroa effect of propolis result}

The control solution of $55 \%$ propolis extract with distilled water, at different concentrations (5\%, 7.5\%,10\%, 15\% and 20\%), at specified times $(5,10,20,30,40,60,75$, and 90 seconds) had no effect at all. The experiment result revealed that $20 \%(\mathrm{~W} / \mathrm{V})$ propolis concentration 


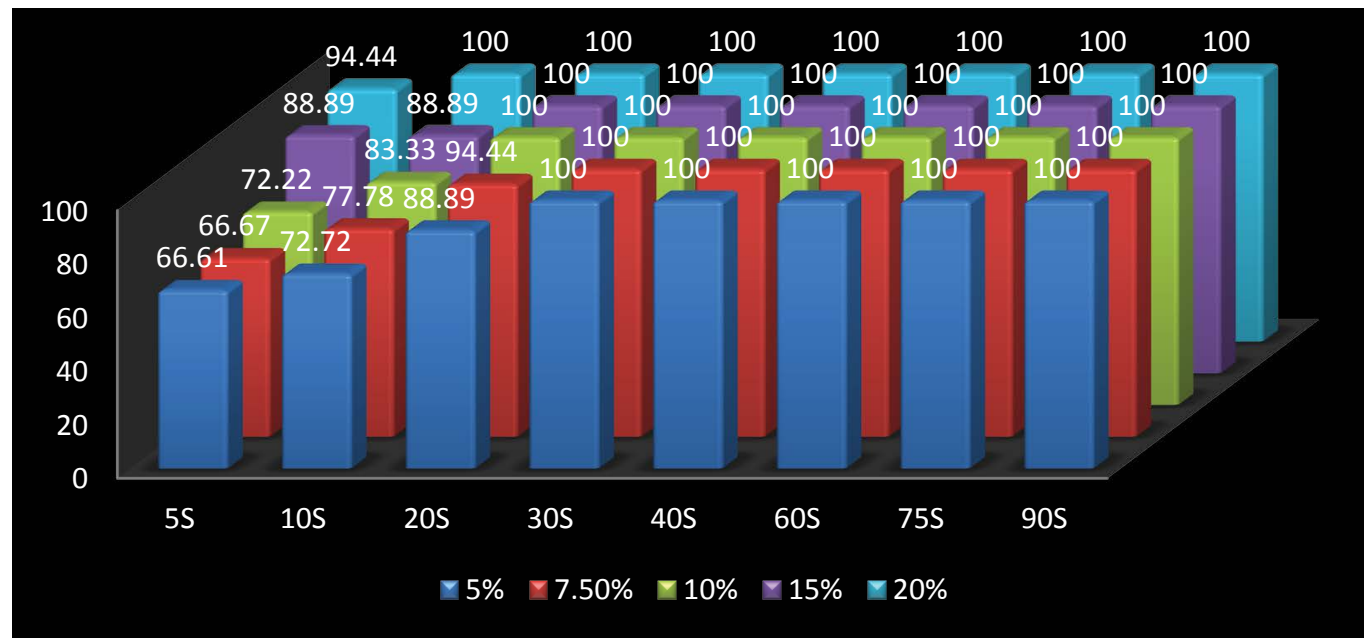

Figure 2: Average effect of propolis at different concentrations, at different times (in seconds)

were highly toxic for mite. It narcotized $100 \%$ within ten seconds and the lowest effect at 10 second was $72.72 \%$ in $5 \%(\mathrm{~W} / \mathrm{V})$ concentration. All propolis concentration type inactivate the whole Mite (100\%) at greater than or equal to thirty second Contact time (Tables 3 and 4; Figure 2).

\section{Questionnaire survey result}

Among interviewed beekeepers, $69(95.8 \%)$ were male and 3 (4.2\%) were females and their educational status were, $21(29.2 \%)$, illiterate, 35 (48.6\%), elementary, 14 (19.4\%), high school and $2(2.8 \%)$ high level. About $69.4 \%$ (50/72) interviewed Beekeepers were did not have awareness of a Varroa Mite. Similarly, among the 22 Beekeepers who knew this mite, only $6(27.27 \%)$ know the damage caused by it. There were no significant variation between risk factor such as, sex, educational status, Peasant Association and duration of experience with awareness of varroa mite and damage of Varroa mite $(\mathrm{P}>0.05)$.

\section{Discussion}

This study revealed that all sampled areas of the Walmara District were tested positive to varroa mites with infestation rate of $15.73 \pm$ $6.9 \%$ Varroa mites per colonies were recorded. The finding agreed with the result $100 \%$ prevalence with average of $15 \pm 7.45 \%$ infestation rate in Tigray Region, Ethiopia [18], 92\% in Tanzania [19], 83\% in Kenya [20] and similar results were also reported in South Jordan [21] and in Sudan Shambat apiary [22]. However, the present finding is higher than previous report $2.33 \pm 0.83 \%$ (mean and standard deviation) for adult bees and $5.06 \pm 2.47 \%$ for brood in Brazil [23]. This finding showed tremendous infestation behaviour of mites (Varroaspp) since they were not obstructed by variations in colony type, Hive type, and vegetation type of an area. Even though high varroa mite infestation was seen in this finding in Brood than Adult it was statistically insignificant $(\mathrm{P}>0.05)$. Although, there is no mechanism explaining why the varroa leaves an adult bee to invade brood cells, it is known that the number of varroas on brood is related to the season of the year and availability of brood in the hive [24,25]. According to Boot et al. [26], the mite enters a brood cell immediately after abandoning the body of an adult bee. Varroas moving on the comb have never been observed, showing that the mite does not look for a specific brood cell to invade. It is known that, to complete their reproductive cycle, adult Varroa females abandon adult bees and invade worker and drone brood cells [23].

\begin{tabular}{|c|c|c|c|c|c|c|c|c|}
\hline $\begin{array}{c}\text { Propolis } \\
\text { Concentration } \\
(\mathbf{w} / \mathbf{v})\end{array}$ & \multicolumn{6}{|c|}{ Average effect of propolis at different times (in seconds) } \\
\cline { 2 - 9 } & $\mathbf{5 ~ S}$ & $\mathbf{1 0 ~ S}$ & $\mathbf{2 0 ~ S}$ & $\mathbf{3 0} \mathbf{S}$ & $\mathbf{4 0 ~ S}$ & $\mathbf{6 0 ~ S}$ & $\mathbf{7 5} \mathbf{S}$ & $\mathbf{9 0 ~ S}$ \\
\hline $5 \%$ & 66.61 & 72.72 & 88.89 & 100 & 100 & 100 & 100 & 100 \\
\hline $7.50 \%$ & 66.67 & 77.78 & 94.44 & 100 & 100 & 100 & 100 & 100 \\
\hline $10 \%$ & 72.22 & 83.33 & 100 & 100 & 100 & 100 & 100 & 100 \\
\hline $15 \%$ & 88.89 & 88.89 & 100 & 100 & 100 & 100 & 100 & 100 \\
\hline $20 \%$ & 94.44 & 100 & 100 & 100 & 100 & 100 & 100 & 100 \\
\hline
\end{tabular}

Table 3: Anti Varroa effect of propolis trials average at different times (in seconds).

On the other hand, it is not certain how and when these mites invaded the honeybee colonies in the districts where mites were found. About 69.4\% (50/72) interviewed beekeepers were did not have awareness of a Varroa mite. However, some of the beekeepers interviewed at different peasant association on Same District, reported that, they were familiar with the pest "Varroa mite" on its presence in honeybee broods they had no prior knowledge on its name "Varroa mite" or its impacts on honeybees. Similarly, among the $22(30.6 \%)$ Beekeepers who knew this mite, only 6 (27.27\%) know the damage caused by it. In this study the majority $(95.8 \%)$ of beekeepers were found to be males. This finding is in line with the study of Beyene and Verschuur [27] who noted beekeeping as the activity of men in Wonchi District of South West Shewa Zone. The limited number of female participation recorded in this study might be due to the fact that, even though all of the beekeeping activities or a part of it was carried out by females was reported as the activity of men. From the total respondents, $68 \%$ of them were attended elementary school to high school which is advantageous for easily grasping of any trainings in general and Beekeeping trainings in particular and apply it into practice to enhance production and productivity of honey and other hive products. However, $29.2 \%$ of respondents were illiterate.

Treatment of mites with propolis causes narcosis and death The narcotic effect of propolis on different animals has already been mentioned in the literature $[28,29]$. The control experiment performed by using distilled water at different times $(5,10,20,30,40,60,75$, and 90 seconds did not shown any effect on the Varroa mites. This finding is Agree with the report of (30) in study of Varroacidal effect of propolis, noted that, contact with water had no effect at all. This may be due to the absence of components of propolis which cause mortality to varroa mites. The present experimental finding revealed 


\begin{tabular}{|c|c|c|c|c|c|c|c|c|c|}
\hline \multirow{2}{*}{$\begin{array}{l}\text { Propolis Concentration } \\
\text { (w/v \%) }\end{array}$} & \multirow[t]{2}{*}{ Repeatability } & \multicolumn{8}{|c|}{ Percentage of inactivated mite at different seconds } \\
\hline & & 5 & 10 & 20 & 30 & 40 & 60 & 75 & 90 \\
\hline \multirow{4}{*}{$5 \%$} & Control & 0 & 0 & 0 & 0 & 0 & 0 & 0 & 0 \\
\hline & A & 50 & 83.33 & 83.33 & 100 & 100 & 100 & 100 & 100 \\
\hline & B & 66.67 & 66.67 & 100 & 100 & 100 & 100 & 100 & 100 \\
\hline & $\mathrm{C}$ & 66.67 & 66.67 & 83.33 & 100 & 100 & 100 & 100 & 100 \\
\hline \multirow{4}{*}{$7.5 \%$} & Control & 0 & 0 & 0 & 0 & 0 & 0 & 0 & 0 \\
\hline & $A$ & 66.67 & 83.33 & 100 & 100 & 100 & 100 & 100 & 100 \\
\hline & $B$ & 66.67 & 66.67 & 83.33 & 100 & 100 & 100 & 100 & 100 \\
\hline & C & 66.67 & 83.33 & 100 & 100 & 100 & 100 & 100 & 100 \\
\hline \multirow{4}{*}{$10 \%$} & Control & 0 & 0 & 0 & 0 & 0 & 0 & 0 & 0 \\
\hline & A & 66.67 & 83.33 & 100 & 100 & 100 & 100 & 100 & 100 \\
\hline & $B$ & 66.67 & 83.33 & 100 & 100 & 100 & 100 & 100 & 100 \\
\hline & $\mathrm{C}$ & 83.33 & 83.33 & 100 & 100 & 100 & 100 & 100 & 100 \\
\hline \multirow{4}{*}{$15 \%$} & Control & 0 & 0 & 0 & 0 & 0 & 0 & 0 & 0 \\
\hline & $A$ & 83.33 & 83.33 & 100 & 100 & 100 & 100 & 100 & 100 \\
\hline & B & 100 & 100 & 100 & 100 & 100 & 100 & 100 & 100 \\
\hline & C & 83.33 & 83.33 & 100 & 100 & 100 & 100 & 100 & 100 \\
\hline \multirow[t]{4}{*}{$20 \%$} & Control & 0 & 0 & 0 & 0 & 0 & 0 & 0 & 0 \\
\hline & A & 100 & 100 & 100 & 100 & 100 & 100 & 100 & 100 \\
\hline & B & 83.33 & 100 & 100 & 100 & 100 & 100 & 100 & 100 \\
\hline & $\mathrm{C}$ & 100 & 100 & 100 & 100 & 100 & 100 & 100 & 100 \\
\hline
\end{tabular}

Table 4: Percentage of inactivated mites at different concentrations, at different seconds.

that $20 \%(\mathrm{~W} / \mathrm{V})$ propolis concentration were highly toxic for mite it narcotize $100 \%$ within ten seconds. This finding is higher than previous research work reported by Garedew et al. [17] 55\% narcotizing rate in twenty seconds. The death of mites in higher amount might be due to Propolis Extraction procedural difference and Acaracide residue in our propolis. Similarly, the narcotizing effect of propolis extracts increases as its concentration increases with the duration of increment of time of contact. This result agrees with the result of Garedew et al. [17], reported that the varroacidal action of propolis increases with increasing concentration and contact of time. In the similar way, the increment of mortality of mites with increment of concentration may be related with the increment of composition of propolis which causes the death of these mites.

\section{Conclusion and Recommendations}

Depending upon the evidence obtained from this study, majority of Beekeepers did not know the damage come with Varroa mite infestation. However, Varroa mite has infested both adult and brood of Honeybee colonies found in selected Peasant Associations of Walmara District. Based on this fact, this pest was one of the most series threats of honey bees which cause reduction in honey production and other hive products that were used. This study justifies the report which noted the presence of Varroa mites in the country at different times. On the other hand, the investigation observed, by conducting experiment that showed the effect of propolis on this mite can be a solution for the treatment of it without fearing of drug residues in honey and other products.

Therefore, depending upon the above facts, the following recommendations were forwarded:

- Varroa mite (V. destructor) which was one of the most threat of Beekeeping activity was found in the District and all the concerned bodies including governmental and non-governmental organizations should participate in the awareness creation for Beekeepers which focuses on prevention and control of this mite.
- Researchers should participate to conduct the effect of propolis on Varroa mites for the treatment of Varroosis and that can be used as commercial raw materials which are not known in our country for income diversification which can increase the economy of Beekeepers and the Country in general.

\section{Competing Interests}

The authors declare that they have no competing interests.

\section{Authors' Contributions}

Dasalegn Begna initiated the research, Ebisa Mezgebu conducted the data Collection and Eyob Hirpa performed the data analysis and drafted the manuscript. The four authors edited and approved the final manuscript.

\section{Acknowledgements}

The authors would like thank the University of Wollega for funding this study. We are also grateful to the Oromia regional State, the western Shoa Walmera district and Holeta bee research institute for facilitating this study. Last but not least, we extend our thanks to all the data collectors and Supervisors.

\section{References}

1. Nazzi F, Brown SP, Annoscia D, Del Piccolo F, Di Prisco G, et al. (2012) Synergistic Parasite-Pathogen Interactions Mediated by Host Immunity Can Drive the Collapse of Honeybee Colonies. PLoS Pathog 8: e1002735.

2. Boecking O, Genersch E (2008) Varroosis-the ongoing crisis in bee keeping. J Verbrauch Lebensm 3: 221-228.

3. Rosenkranz P, Aumeier P, Ziegelmann B (2010) Biology and control of Varroa destructor. J Invertebr Pathol 103: S96-S119.

4. Genersch E (2010) Honey bee pathology: current threats to honey bees and beekeeping. Appl Microbiol Biotechnol 87: 87-97.

5. Wallner K (1999) Varroacides and their residues in bee products. Apidologie 30: $235-248$.

6. Imdorf A, Bogdanov S, Ibaez Ochoa R, Calderone NW (1999) Use of essentia oils for the control of Varroa jacobsoni Oud. in honey bee colonies. Apidologie 30: 209-228.

7. Ghisalberti EL (1979) Propolis: a review. Bee world 60: 59-84. 
Citation: Mezgabu E, Hirpa E, Begna D, Yimer L, Bayan A, et al. (2016) Occurrence and Distribution of Varroa Mite and Antivarroa Effect of Propolis in Walmara District of Oromia Special Zone Around Finfine, Ethiopia. J Vet Sci Technol 7: 370. doi: 10.4172/2157-7579.1000370

Page 6 of 6

8. Castaldo S, Capasso F (2002) Propolis, an old remedy used in modern medicine. Fitoterapia 73: S1-S6.

9. Park YK, Alencar SM, Moura FF, Ikegaki FFM (1999) Atividade biológica da própolis. Revista OESP-Alimentação 27: 46-53.

10. Geraldini CAC, Salgado EGC, de Mello Rode S (2010) Ação de diferentes soluções de própolis na superfície dentinária-avaliação ultra-estrutural. Brazilian Dental Science 3: 28-32

11. Auricchio MT, Bugno A, Almodóvar AAB, Pereira TC (2006) Avaliação da atividade antimicrobiana de preparações de própolis comercializadas na cidade de São Paulo. Revista do Instituto Adolfo Lutz (Impresso) 65: 209-212.

12. König B, Dustmann JH (1988) Baumharze, Bienen und antivirale Chemotherapie. Naturwissenschaftliche Rundschau 41: 43-53.

13. Walmara District Livestock and Agricultural Office (2014) Walmara District. Oromia Special Zone around Finfine, Ethiopia.

14. Thrusfield M (2007) Veterinary Epidemiology. 3rd edn. Blackwell science Ltd., UK, pp: 182-198.

15. Fries I, Aarhus A, Hansen H, Korpela S (1991) Comparison of diagnostic methods for detection of low infestation levels of Varroa jacobsoni in honeybee (Apis mellifera) colonies. Exp Appl Acarol 10: 279-287.

16. Strehl E, Volpert R, Elstner EF (1994) Biochemical activities of propolis-extracts III. Inhibition of dihydrofolate reductase. Z Naturforsch 49: 39-43.

17. Garedew A, Lamprecht I, Schmolz E, Schricker B (2002) The varroacidal action of propolis: a laboratory assay. Apidologie 33: 41-50.

18. Begna D (2015) Occurrences and Distributions of Honeybee (Apis mellifera Jemenetica) Varroa Mite (Varroa destructor) in Tigray Region, Ethiopia. J Fisheries Livest Prod 3: 126.

19. Mumbi CT, Mwakatobe AR, Mpinga IH, Richard A, Machumu R (2014) Parasitic mite, Varroa species (Parasitiformes: Varroidae) infesting the colonies of
African honeybees, Apis mellifera scutellata (Hymenoptera: Apididae) in Tanzania. J Entomol Zool Stud 2: 188-196.

20. Muli E, Patch H, Frazier M, Frazier J, Torto B, et al. (2014) Evaluation of the distribution and impacts of parasites, pathogens, and pesticides on honey bee (Apis mellifera) populations in East Africa. PloS one 9: e94459.

21. Al-Chzawi AAMA, Zaitoun ST, Shannag HK (2009) Incidence and geographical distribution of Honeybee (Apis mellifera L.) pests in Jordan. In Annales de la Société Entomologique de France 45: 305-308.

22. El-Niweiri MAA, El-Sarrag MSA, Satti AA (2008) Survey of diseases and parasites of honeybees (Apis mellifera L.) in Sudan. SJBS Series B: Biol Sci 14: 141-159.

23. Eguaras M, Marcangeli J, Oppedisano M, Fernández N (1994) Seasonal changes in Varroa jacobsoni reproduction in temperate climates of Argentina. Bee Sci 3: 120-123.

24. Moretto G, Leonidas JDM (2003) Infestation and distribution of the mite Varroa destructor in colonies of Africanized bees. Braz J Biol 63: 83-86.

25. Boot WJ, Sisselaar DJ, Calis JN, Beetsma J (1994) Factors affecting invasion of Varroa jacobsoni (Acari: Varroidae) into honeybee, Apis mellifera (Hymenoptera: Apidae), brood cells. Bulletin of Entomological Research 84: 3-10.

26. Boot WJ, Beetsma J, Calis JN (1994) Behaviour of Varroa mites invading honey bee brood cells. Experimental \& applied acarology 18: 371-379.

27. Beyene T, Verschuur M (2014) Assessment of constraints and opportunities of honey production in Wonchi District South West Shewa Zone of Oromia, Ethiopia. American Journal of Research Communication 2: 342-353.

28. Prokopovich NN, Flis ZA, Frankovskaya ZI, Kope'eva EP (1956) An anaesthetizing substance for use in stomatology. Vrachebnoe Delo 1: 41-44.

29. Prokopovich NN (1957) Propolis a new anaesthetic. Vrachebnoe Delo 10: 1077-1080. 